\title{
The Ills of Colonial and Post-independent Kenya as Reflected in Imbuga's Betrayal in the City
}

\author{
Théoneste Nsabimana
}

Lecturer, English and Literature in Catholic University of Rwanda, Rwanda

Received: 04 Nov 2021; Received in revised form: 05 Dec 2021; Accepted: 11 Dec 2021; Available online: 21 Dec 2021

(C)2021 The Author(s). Published by Infogain Publication. This is an open access article under the CC BY license

(https://creativecommons.org/licenses/by/4.0/).

\begin{abstract}
This study is a qualitative analysis of the problems of Kenyans after independence. The researcher highlighted all kinds of evils faced by the mass population such as political betrayal and revenge, social injustice, corruption, nepotism, privilege and dictatorship to name a few. The researcher critically analyses the play "Betrayal in the City", and came up with possible solutions to overcome the ills listed above like unity, forgiveness and reconciliation in order to build a peaceful nation. The researcher had not only suggested truth, forgiveness and reconciliation as a key towards unity and sustainable peace building among people but also the relevance of the study to the society has been put in the readers' hands.
\end{abstract}

Keywords-Betrayal, Kenya, independence, socio-political issues

\section{INTRODUCTION}

Francis IMBUGA's Betrayal in the City is a focus to our study. It examines the problems of independence and freedom in post-independent Kenya where a great number of people feel that their future is either blank or bleak. They want to stress that at last their socio-political situation in colonial era was better than that they are living. This is found in the words of Mosese, one of the characters in the play. "It was better while we waited. Now we have nothing to look forward to. We have killed our past and are busy killing our future." (Imbuga, 1976, p.31). Our literary study, "The Ills of Colonial and Post-Independent Kenya as Reflected in Imbuga's Betrayal in the City", will analyze and highlight all the evils characterized postindependent Kenyan political regime such as injustice, corruption, nepotism, betrayal, revenge, dictatorship and continuous killings of the innocent. It is in this context that the researcher will investigate the relevance of themes related to the evils above for the Kenyan community and even beyond and also find out how forgiveness and reconciliation is the cornerstone of national unity and sustainable peace building.

\section{Statement of the problem}

Like many other African committed playwrights, Imbugadepicts how post-independent African leaders plunged their citizens into human suffering such as betrayal, revenge and violence which caused death in some circumstances. Imbuga and other African writers focus on the burning issues such as the abuse of power which produces various consequences namely betrayal and revenge among black people, oppression, social inequalities, injustice and many other evils. For this reason, lack of responsibility creates two opposite sides: the oppressed group constituted by the ruled masses characterized by fear and lack of freedom of expression. Then, the oppressor composed of a small class of elites now in power characterized by dictatorship. As such, this study discusses different themes which reflect the ills of both colonial and post independent Kenyan community. The researcher highlights how politicians in postindependent Kenya play a great role in creating conflicts among citizens; thus, the socio-political issues reflected in Imbuga's Betrayal in the city.

\section{Study questions and objectives}

This study analyses the socio-political issues reflected in Betrayal in the City. The researcher wants to find out answers to the following questions related with the evils 
that characterized post-independent Kenya. 1) Why do post-independent political leaders betray their fellow citizens? 2) What are the causes of all the ills faced by post-independent Kenyan society? 3) Is forgiveness and reconciliation between betrayers and betrayed possible in such context? 4) What is the relevance of Betrayal in the City to the African community? Inline with these questions, the study is guided by the following objectives:1) To explain how post-independent political leaders are the main promoters of the Africans' misery. 2) To find out the messages conveyed throughout this study. 3) To investigate the relevance of themes related to the ills of post-independent Kenya for the Kenyan community and even beyond. 4) To prove how forgiveness and reconciliation are the cornerstone of national unity and sustainable peace building.

\section{Significance of the study}

In consideration with both my domain of study and interest in worldwide literature in general and Kenyan literature in particular, the researcher found it important to direct his research on Francis Imbuga's play "Betrayal in the City". For a lecturer of literature in English, it is a fine literary work to study. In addition, this play portrays issues that Africans should keep in mind, for it is a part of our history. Among many other facts that captivated my attention is the way Imbuga as a playwright tries to suggest solutions to these problems especially reconciliation and forgiveness. However, it is well known that African society has known a lot of history as far as colonialism is concerned. For this reason, different African communities are still suffering from the ills of the past such as oppression, nepotism, corruption, betrayal, revenge etc. People kill others for no reason. So, this study will urge people specifically East African Community members and others who will read this research study to be aware of the extent of those problems so that they devise strategies to address them. Imbuga`s Betrayal in the City can also be a good example to Rwandans who experienced the unpleasant events of 1994 genocide against Tutsi. Readers, Rwandans specifically, will draw from it how Imbuga tries to solve current issues through the channel of reconciliation and forgiveness.

\section{LITERATURE REVIEW}

Imbuga is one of the prominent African playwrights whose interest lies in African political situation after colonialism. Many African countries, including Kenya, experienced various evils which prevented people from enjoying the fruits of independence they had fought for many years ago. That is why the themes of betrayal, revenge, injustice, corruption, favoritism, nepotism, violence and dictatorship to name few are more developed in his Betrayal in the City, a play which attracts the researcher's attention in this study. The Macquarie Dictionary (1991) lists a number of different, though closely related, meanings of the term "betray" including to deliver up to an enemy, to be disloyal or unfaithful, to deceive or mislead, to reveal secrets, to seduce and desert, and to disappoint the hopes or expectations of another. The term "betray" also means to give up treacherously a person or thing to enemy; be disloyal to; lead astray; reveal treacherously or involuntarily(Harper,1968). Macmillan English Dictionary for Advanced Learners (2002) defines it as follows: "If you betray your country, or you betray someone who needs your support, you deliberately do something that harms them or helps their opponents." Someone who betrays others is commonly called a traitor or betrayer. Boveri (1971) in her De la Trahison au XXè siècle has defined a betrayer in these terms:

Un individu est un traître à nos yeux
lorsqu'il nous donne l'impression d'être
un ami, un disciple, un démocrate, un
nationaliste, un citoyen fidèle, un
compagnon de lutte, un soldat discipliné,
un membre d'une secte et que, en réalité,
ses pensées et ses actions vont dans le
sens contraire : qu'il dénonce l'ami,
renie le prophète, ouvre contre le chef
idéologique, nuit à la démocratie, à la
nation, soutient l'ennemi de l'Etat, se
convertit à une autre foi (p.103).

Someone is a betrayer for us when he gives the impression of being a friend, a disciple, a democrat, a nationalist, a loyal citizen, a comrade in wrestling, a disciplined soldier, a member of a sect and that, in reality, his/her thoughts and actions are the other way round, that is, they denounce their friend, deny the prophet, act against the ideology, democracy and the nation, support the enemy of the State, and convert to another faith. (Translation is mine.)

Considering this definition, one may say that it turns around the idea that a betrayer gives an impression of being an angel while he is the opposite. Consequently, once a person discovers that he/she has been betrayed, a hatred feeling rises and very often generates into violent conflict according to the level of betrayal and this may lead to revenge. The theme of treachery and betrayal has figured in many works of literature. In Chinua Achebe's $A$ Man of the People, we have a situation in which politicians 
betray the mass of the people for their own selfish material ends. Here, with the author's connivance, we take a moral stand against him. InNgugi(1973), betrayal takes a psychological and more complex stature. Mugo's betrayal of Kihika is by no means a clear cut case in which we take a stand against him. Indeed, in him we see betrayal as a human weakness with which we fully sympathize,Gecau (1973). In this context,Ngugi is another important African writer who cannot be left behind. In Weep Not Child he criticizes some Africans for betraying their fellow neighbors during colonial era. Jacobo plays the role of traitor in colonial Kenyan community. He betrayed Ngotho, Njoroge's father, the main character in the novel.Along the same lines, Ngugi (1964) displays different characters whose main concern is betrayal. First of all, when Gikonyo was imprisoned, Mumbi, his wife was ultimately forced to sleep with Karanja who had been appointed village chief by the colonial power through collaboration. In this regard, instead of enjoying the fruits of independence they had fought for many years ago, Africans were deceived and disillusioned by a small group of educated elites who betrayed the mass population and did not put much consideration to the development of their countries. They were only interested in their own benefits instead of establishing strong political institutions and economic development policy.According to Wilson (2001, p.162), revenge applies to the unchecked violent acts of individuals and armed gangs motivated by the desire for vengeance with no element of proportionality. Verdier (1980, p.15) argues:

\section{Notre conception moderne occidentale de la vengeance la réduit à une simple réaction individuelle, plus ou moins spontanée, à une offense, suscitée par la pulsion, le besoin ou le désir à infliger un mal, une souffrance à celui qui nous a causé un tort. Our Western modern conception of vengeance reduces it to an individual simple reaction at least spontaneous, to an offense, aroused by the impulse, the need or the desire to inflict pain, suffering on someone who wronged us(Translation is mine).}

According to Sykes (1982), Vengeance is defined as a punishment inflicted or retribution exacted for wrong to oneself or to person etc. whose cause one supports. Vengeance refers to a language and an emotion of reciprocal punishment and suffering of the offender as compensation for wrongdoing or perceived harm (Wilson: 2001, p.162). Why do people revenge? This is a question many people ask themselves trying to find out some causes of revenge within society.Steinmetz cited in Verdier (1980, p.16) providespsychologicalexplanation of vengeance: On se venger parce qu'on a du plaisir à infliger de la douleur-il proposait une interprétation religieuse : La vengeance serait un effet du culte des morts, les proches doivent venger le mort parce que son esprit crie vengeance. We take revenge because we have pleasure to inflict pain-he proposed a religious interpretation: revenge would be cult of the dead; relatives must avenge the dead person for his spirit cries for vengeance (Translation is mine). Within the same source, Verdier (1980, p.117) points out another reason that can provoke a person's revenge. He writes: Pour clorer la liste des offenses susceptibles de provoquer la vengeance, il faut encore mentionner celles qui ressortissent du verbel'insulte et la malédiction. [...] Un homme digne de ce nom n'accepte pas une insulte. To come to an end of the list of susceptible insults to provoke revenge, it is also better to mention those which come out the word-insult and malediction. [...] A person worthy of the name does not accept insult. What motivates betrayed individuals to take vengeance on their betrayers? This is another question which cannot be left behind without an answer. Clearly, one important motive is that revenge helps even the score between the two parties. In this sense, revenge and guilt are functionally similar in that both help to share the pain-causing one's betrayer to suffer.According to Nietzsche (as cited in Wilson, 2001, p.159), revenge is a kind of respect and dignity. He recognizes its universality and undeniable force and argues that it cannot be suppressed without consequences. He also asserts that the emphasis on mercy in the Judeo-Christian tradition was a veiled reaction to the repressed desire for revenge. The Holy Bible tried to moderate the allowed damage in order to avoid a vendetta or series of violent acts that could spiral out of control-instead of vengeance, there would be a simple equality of suffering. This is found in the Old Testament as follows: "But if there is serious injury, you are to take life for life, eye for eye, tooth for tooth, hand for hand, foot for foot, burn for burn, wound for wound, and bruise for bruise. (Exodus 21:23-25.) Referring to Roman Scripture, some Christians say that only God has the moral act to exact revenge: "Do not take revenge, my friends, but leave room for God's wrath, for it is written: "It is mine to avenge; I will repay," says the Lord. (Romans: 12:19.) Hugo (as cited in Verdier1980, p.36) shares the sameviewswith the above assertion: Se venger est de l'individu, punir est de Dieu. La société est entre deux. Le châtiment est au-dessus d'elle, la vengeance audessous : Rien de si grand et de si petit ne lui sied. Elle ne doit pas «punir pour se venger. » Elle doit corriger pour améliorer. To revenge is for individual, to punish is for God. The society is between the two. The punishment is 
upon it, the vengeance underneath. The society mustn't "punish for revenge." It must correct in order to improve. (Translation is mine.) As it has been said above, revenge is not a reliable solution to betrayal or other kinds of violence for it breaks the unity among individuals and communities. For this Reason, Gamois one of the societies that include revenge as response to aggression: D'une part, au niveau individuel, la vengeance est conçue comme une faute grave envers les forces surnaturelles. D'autre part, si la société Gamo exclut la vengeance comme réponse à une agression, ce n'est pas seulement pour des 14 raisons éthiques, c'est surtout une menace pour l'unité de la société politique,Verdier (1980, p.213). On one hand, on the individual level, revenge is conceived as a serious fault towards supernatural forces. On the other hand, if the Gamo society excludes revenge as response to aggression, this is not only for ethical reasons; it is particularly that revenge is considered as a threat for unity of political society. (Translation is mine.) Within the same line of ideas, revenge is not the right answer again to those who have wronged us for revenge causes you to act blindly through anger, rather than through reason. It is based on the principle of eye for an eye, but this principle is not always a clever theory to live by. Therefore, it is also difficult to know exactly what kind of punishment is enough to make justice. For instance imagine if someone kills your wife, then you go and kill his wife too. However, you work and he does not. So, his children starve because their mother who used to buy them food is dead. And then the children are innocent. Is it justice? Here, people never know how their reactions will affect the life of others. Another example which illustrates the consequences of revenge is when everybody retaliated when they felt someone had done them wrong. The world would be chaotic, because making mistakes is part of human nature. We all make mistakes, and many times those mistakes hurt other people. Today there are killings all over the world and people are proud to say they would make someone pay if they did them wrong. And that is why the world is so chaotic today. Consequently, different writers highlight various effects of revenge as far as different situations are concerned. Verdier (1980, p.163) argues: «La vengeance qu'exige la coutume me parait en effet conçue comme subordonnée à la justice et proche à l'idée de réparation pénale, c'est-à-dire du rétablissement d'un équilibre qui permettra la reprise des échanges sociaux pacifiques. Certes, la violence initiale peut engendrer une haine, un ressentiment ou une rancune ouvrant la porte à une vengeance psychologique qui sera apparemment une pure réaction passionnelle, allant jusqu'au sadisme vis-à-vis des prisonniers de guerre par exemple». The revenge that custom requires seems to me in fact conceived as a subordinate to justice and close to the idea of penal reparation, that is, restoration of balance which permits pacific social exchange to be resumed. Indeed, the initial violence can give rise to a hatred, a resentment, or a grudge opening the door to psychological revenge that will be apparently a pure passionate reaction, coming up to sadism vis à vis prisoners of war for example. (Translation is mine). According to Wilson (2001), the acts of revenge would cause people to continue thinking about the transgressor whom they have punished, which would prolong their hedonic reactions to the transgression rather than shorten them. Thus, he continues saying that people punish others, in part, to repair their negative mood and to provide psychological closure to the precipitating event, but that act of punishment yields precisely the opposite outcome. Viljoen (as cited in Bronkhorst, 1995, p.67) is of the opinion that God is the appropriate judge; he switches from English to Afrikaans in order to say something very close to his heart: "God is die finale wraaknemer. Dit is nou die tydommekaaraan to neem." [ "God is the final avenger. This is now the time to accept each other."] However, after seeing that revenge is not the appropriate solution to betrayal, this brings us to ask ourselves if forgiveness can work in this context. According to the electronic source http://www.psychcentral.com/lib/2007, the term forgiveness means letting go of the need for revenge and releasing negative thoughts of bitterness and resentment. Moreover, forgiveness is not forgetting or pretending it didn't happen. It did happen and we need to retain the lesson learned without holding onto the pain. Furthermore, considering this definition, we can see that forgiveness is deep in the human heart. And here people should know the reality of God's forgiveness for without it, their lives can be locked up in guilt and anger. We should learn how to forgive even though we sometimes face the challenge of extending this forgiveness to those who have betrayed us. To this point of view, MacGinnis (1979, pp.156-157) states: The forgiving person is sometimes caricatured as weak and spineless, but just the opposite is true. One must be strong to forgive, for forgiveness is a very positive force. [...]Just as bitterness produces more bitterness in others, so love begets love. Thank God for those dynamic, creative people who, when wronged, refuse to compound the amount of hate in the world. Instead of returning the blow, they forgive. Forgiving also helps to recall how generously we have been forgiven by God by referring to His prayer: "Father, forgive us our trespasses as we forgive those who trespass against us." According to this prayer, if we never sin we do not have to forgive but if we sin we have to do so for it helps us to reflect on how much God has forgiven us, and it makes our own little grudges against others seem rather 
petty. Thus, one may say that forgiveness may be considered simply in terms of the person forgiven and in terms of relationships between the forgiver and the person forgiven. To some context, it may be granted without any expectation of restorative justice and without any response on the part of the offender. In practical terms, it may be necessary for the offender to offer some form of acknowledgement, apology or even just ask for forgiveness, in order for the wronged person to believe himself able to forgive. In addition, another important solution over betrayal and revenge is that of unity and reconciliation. According to Macquarie English Dictionary (2002), reconciliation means a new and friendly relationship with someone you argued with or fought with. Whereas unity is a situation in which a group of people or countries work together for a particular purpose. Referring to this definition, one can say that apart from forgiveness, unity and reconciliation can serve as strong solutions to overcome conflict, betrayal and revenge. Therefore, they can be considered as the basis for durable peace, security, human rights, and development. Tutu (as cited in Wilson, 2001, p.120) introduces forgiveness and reconciliation as a way to a peaceful and healing process: Forgiveness is not conditional upon the wrongdoer expressing remorse or asking for forgiveness, but is a duty incumbent upon all victims. There are no unforgivable perpetrators, no person who cannot be redeemed and this redemption also "liberates the victim."[...] any expression of a desire for revenge by victims would seem out of place. Virtues of forgiveness and reconciliation were so loudly and loudly applauded, that emotions of vengeance, hatred and bitterness were rendered unacceptable, an ugly intrusion of a peaceful, healing process. Intentionally, truth and reconciliation are steadily becoming more important issues. Reconciliation is as relevant for the international community as for the nation itself. One of the most shocking features of international politics is that some governments have never been held responsible for massscale killings, even though the same government remained in power long afterwards. However, central to the process of reconciliation, and indeed to all work for human rights, stands the need to establish the truth. Without truth no justice can be done, no mediation can bring results, and compensation measures lack real meaning. It is also said that no true reconciliation is possible unless there has at the very least been the chance to bring the worst offenders to justice,Bronkhorst (1995, pp.145, 152). Truth, then, the recognition and acknowledgement help to provide the basis for a workable political community; it will help to provide it with legitimacy and durability. Truth is only useful to reconciliation in some ways and: "unless it is joined to a form of justice other than punishment, the recognition of truth is likely to breed outrage in victims and fear in beneficiaries," Christie (2000, p.180). Any genuine reconciliation is not possible without the telling of the truth and without the public acknowledgement of that truth: There can hardly be reconciliation without an acknowledgement of the wrongs being done to the victims of human rights violations, without the nation as a whole participating in the healing process... it is fallacy to believe that reconciliation can be built on the basis of collective amnesia, Christie (2000, p.164). Justice is another relevant point that needs discussion in this study. Macmillan English Dictionary for Advanced Learners (2007, p.820) defines justice as treatment of people that is fair and morally right. Most importantly, a world that is socially just would be one in which people are treated fairly - everybody deserving and receiving an equal slice of the cake. Mahatma Gandhi (as cited in Ryan, 2015, p.115), said: "I have no right to more than I need when my brother/sister has less than they need." However, people, in this post-independent corrupt society, lacked social justice. It would be difficult for us not to notice where social justice is missing in today's world. Social injustice is one of the most striking evils in Post-independent Kenya. Ryan (2015, p.116) puts it that social injustice is where people in our society do not receive equal access to resources and opportunities, such as a home or an education. Moreover, in this study, not only have betrayal, revenge and social injustice as the major evils in Betrayal in the City been paid attention to but also other elements have been given room by various critics. Awoonor (as cited in Muzerwa, 2006) claimed that after the departure of white colonialists, the black elites rushed to occupy the places vacated by the colonizers. Their primary interest was to enrich themselves to the detriment of the whole population. As a result, the population continues to undergo harsh living conditions as they did during the colonial period. As a matter of fact, politicians played a significant role in the suffering of the people in Ghana and in Africa in general. In addition, the desire of power and property led these African elites to corruption, nepotism and dictatorship which hindered the development of the country. A good example is Achebe's A Man of the People and Imbuga's Betrayal in the City. However, in Betrayal in the City (1987:47),Imbuga articulates this same mentality of "eat and eat" philosophy through Tumbo i.e. stomach, who says that a man eats where he works. For Bayart, this partly leads to the hilarious subtitle for his work, "Politics of the Belly". It is an approach to the post-colonial African States in which any actor, worthy of the name tries to get a mouthful, (Bayart, 1993, p.90). In A Grain of Wheat (1967) Ngugi highlights corruption through security institutions as one the evils that hindered the development of the Kenyans 
after independence. Nepotism is another kind of corruption initiated by post-independent African leaders. Wikipedia, the free encyclopedia defines nepotism as favoritism granted to relatives. Ssenyonga (2012, p.362) posits that nepotism is favoritism shown to relatives or friends especially by giving them jobs. Besides corruption and nepotism committed by most of post-independent African countries, dictatorship is also one of the ills which characterized post-colonial era. A dictatorship is a government headed by a dictator. The term "dictatorship" means a government in which absolute power is concentrated in the hands of a dictator, and sometimes his cronies, (Ryan, 2015, p.24).

\section{THEORETICAL FRAMEWORK}

This study is framed on various literary theories such as nationalism, neo-colonialism, capitalism and postcolonialism. By highlighting and analyzing deeply the ills of colonial and post independent Kenya, the researcher has given an overview on each of the above theories by demonstrating how they fit for this study whereby the study of themes and characters are in one way or another interconnected elements in a literary analysis. Nkrumah (1965) states that the results of neo-colonialism is that foreign capital is used for the exploitation rather than for the development of the less developed parts of the world. He goes on saying that investment under neo-colonialism increases rather than decreases the gap between the rich and the poor countries of the world. In his neo-colonialism theory, Nkrumah also declares that economic unity to be effective must be accompanied by political unity as the two go hand in hand. This theory best fits for the sociopolitical situation in post-independent Kenya whereby the Boss of Kafira is doing his best to please the Head of State on the visiting occasion. Moreover, the study shows how political weakness hampers the economic growth of the country. This is proven by capitalism theory which favors the greatest possible profits for minority group of people ignoring the others especially lower social class. The last but one, one cannot understand the ills of post-independent Kenya without putting into account the nationalism theory. Cambridge Online Dictionary defines "nationalism" as the desire for and the attempt to achieve political independence for your country or nation. With reference to the definition, the researcher chose the nationalism theory to help him analyze critically all evils arising in Kenya after getting independence in 1963. People who fought for independence were ignored, disappointed and disillusioned. Ogungbsan (1978, p.6) says that the African politicians who took over the reins of governance from the white colonialists are corrupt, selfish and worse than the colonial masters. African writers and people discovered too late that "the ruling elite was more interested in considering its own dominance and in monopolizing the continent's natural resources than in improving the abject condition of the common people." Finally, postcolonialism has been defined as a theory which encapsulates the totality of practices which characterize post-colonial African societies from the emergence of colonialism to the present day. Eduard Said, the father of post-colonialism theory, believes that the consequences of colonialism are still persisting in the form of Chaos, coups, corruption, civil wars and bloodshed, which permeates many ex-colonies (Hamadi, 2014). This theory together with other theories discussed briefly above complete one another and have facilitated the researcher to analyze Imbuga'sBetrayal in the City as far as themes and characters in relation with the ills of post-independent Kenya are concerned.

\section{METHODOLOGY}

The purpose of the researcher was to deal with the ills of colonial and post-independent Kenya. The study based on document analysis. The data were obtained from both primary and secondary sources. The primary source is the play under the study, Betrayal in the City by Francis Imbuga. The secondary sources are other documents in relation with the ills of colonial and post independent Africa. Takinginto account the type of this study, both sociological and historical approaches have been very useful in the interpretation of Imbuga's Betrayal in the City. These approaches were focused on for their reliable intervention in analyzing socio-political issues of any given society because literature cannot be disconnected from society and it consists of life experience of the people in the society. Ogundele (as cited in Bazimaziki, 2016) posits that literature is more or less equated with history. So this study also focuses on historical events of colonial and post-independent Kenya. In addition, this is a literary study. As cited in Bazimaziki (2016), Professor Jenkins Rob in his Literary Analysis as a Scientific Method claims that the scientific method in literary studies broadly consists of three main steps such as observe, hypothesize and experiment. I also agreed with him and resorted to method for these three steps are very relevant in this type of literary analysis. He explains that a poem or a work of art can be interpreted simply by applying the scientific method as defined above. Besides, psychological approach especially its specific area of thematic approach was also put into consideration as far as thorough analysis of themes and characters are concerned. Thus, the researcher used qualitative analysis to analyze the data. Quotations and 
passages were extracted from primary and secondary sources and were commented on analytically. Quotations from primary source were directly or indirectly supplemented by information from secondary sources. Data were analyzed basing on post-colonialism, neocolonialism, nationalism, and capitalism theories.

\section{DISCUSSION}

Imbuga is among the greatest African playwrights who tried to highlight sociopolitical problems of Africans from colonial to post-colonial African society in general and Kenyan community in particular. This playwright played an important role in post-independent Kenya where he portrays the evils of political leaders and the suffering of the mass through his play, "Betrayal in the City".This study discusses and analyzes critically the ills of postindependent Kenyan community with the accession of Kenya to independence. People had the idea that there would be change in socio-political organization. After the independence, the masses were still undermined as in the colonial period. This was due to the black rulers who were more interested in making a lot of property instead of improving life conditions of their citizens as promised. For many people, it was better while they waited for nothing changed since they have got independence. In this section, the researcher analyzes the ills of post-independence like political betrayal, corruption, nepotism, privilege, illiteracy and so forth. Revenge inflicted by both oppressors and oppressed was not also left out. He also reveals how the ruling class ill-treats the mass which results in revenge and betrayal. In the same line of ideas, the researcher develops the theme of lack of trust among Kenyan citizens as well. These ones do not trust their government officials for the reasons highlighted above. As a solution, the researcher has highlighted how Imbuga suggests unity and reconciliation as a strong foundation of a better future where there would not be betrayal, revenge, and oppression any more. The discussion begins with politicians in portraying betrayal. After getting independence, Kenyan elites ruled the country. People were expecting to see changes in their life as far as different domains are concerned. Therefore, the failure of independence is regarded as the sign that the elites have failed to prove their competence and common-sense as leaders. Apart from betraying the promises they made during the struggle, post-independence leaders are accused of creating a standard of living out of proportion and marginal to the community. Obiechina(as cited in Mukama,1999, p.29) displays this incompetence of leaders and exploitation of their positions: The government had committed itself to bring about greater equality, yet it was the government officials themselves who were far above the masses in education, income, social status and political power; hence the officials would be the first to suffer losses from any leveling reforms they might institute. This conflict of interest proved difficult, if not impossible to resolve. However, the incompetence of Kenyan leaders played a great role to portray the theme of betrayal. Imbuga portrays this through the Boss of Kafira. This one fails several times to solve political and social betrayal. He is supposed to maintain order and protect people's rights but he is not. In this regard, Mulili, one of the Boss's counselors directed many accusations against Kabito to the Boss. Yet, the latter failed to solve this problem carefully and commanded the guilt's death. (Imbuga: pp.62-63). Apart from incompetence of the Boss to make decisions and judge reasonably various cases reported by his fellow leaders, one may consider betrayal as a dominant feature in the above passage. Moreover, political betrayal may be found all along the play.Jere: What did they charge you with? Weeping in public? Mosese: No. Being in possession of an illegal drug. One kilogramme of opium. When they searched my car, they sure enough found the drug. I laughed. I had heard similar stories, but I never thought it would ever happen to me. The man who planted it on me was called Nicodemus (p.29). Taking into consideration this quotation, we can see how Nicodemus, one of the government officials betrays Mosese, a University lecturer. Here, leaders are supposed to be the ones to uproot the problems that people are suffering from. But now, they are at the top to betray them. In addition, Mulili, a soldier and appointed official in the entertainment committee also betrayed Jere his fellow soldier due to the disagreement about letting Doga and Nina go on or not with funeral ceremonies of their son, Adika shot while participating in the students' demonstrations. As a result, Jere was jailed (pp.21-22). Tumbo, a government official also betrayed his fellow citizens. He knew well what they wanted when they were fighting for freedom. But now he does not want to stand up and show the truth to the Boss of Kafira whereby he even warns Jusper not to tell the nude of truth in his entertaining play. He wants him only to praise the government by including the word progress and achievement. Jusper: Absurd. It is the only way to safely get the truth across. Only a few things are in black and white; the rest in darkness. Tumbo: Just the kind of play we need for the great day. A play that will outline our achievements in black and white and ignore the dark side of the picture. Do you think you can write one for that purpose? Tumbo: Go get the new rehearsal schedule, and remember: one faulty step, and your university studies could come to an abrupt end. Already you have lost more than a year. Jusper: I don't mind losing another if that is 
what it means to stand for truth and justice. Tumbo: If you knew what has happened to one of us on the committee, I am sure you would postpone your eagerness to stand by truth and justice (pp.51, 65). Finally, at the end of the play, we see how Mulili develops the theme of betrayal to the point that he even betrays the Boss, his own cousin. This is strange. This happened when prisoners were asked to perform a play in the intension of welcoming the Head of State.Jusper: You waste time, pin him down. I said, pin him down. Alright, let me do it. Squad, attention! Aim, one, two, three, two, one tututututu!!!!!!!!!! Squad at ease! To (Mulili) Hey, sergeant! Why so sad, eeh? He your cousin or something?Mulili: Oh, no, no, is never! ... Jere: I will show you why. Mulili, come towards me. (Mulili obeys). This man is your cousin. Mulili: He is only distant cousin, that is all. Jere: Give me one reason why he should not be killed. Mulili: No reason. You can kill. Jere: Do you agree that he should be got rid of? Mulili: Kabisa! One, he take everything in his hand. Two, he spoil the economic of Kafira. Three, he rule too long. Change is like rest. Four, he kill Kabito. Boss: Am I hearing right? Mulili? (toJere) Shoot me. Spare me this betrayal. Shoot me (pp.75-76)! In this regard, revenge was also considered as a major evilthat characterized Kenyans during and after independence. According to Macmillan English Dictionary for Advanced Learners (2007,p.1274) revenge is defined as something that you do to hurt or punish someone because they have hurt you or someone else. However, this act of revenge may involve different parties be it victims or victimizers. That is why hereunder I have discussed the oppressor's revenge and oppressed revenge as major elements in the play.On one hand, let us start with oppressor's revenge. According to Wikipedia, the free encyclopedia, oppression derives from the concept of being weighted down, and is often depicted as such. Social oppression has in recent times been an epiphenomenon of various types of social dysfunction, whereby discrimination against an identified group is stimulated, encouraged and reinforced by way of promoting antagonism towards the other. The term itself is derived, in a direct experiential sense, from the sensation of being pushed or lifted up by a greatly superior force. Oppression is the exercise of authority or power in a burdensome, cruel, or unjust manner. It can also be defined as an act or instance of oppressing, the state of being oppressed, and the feeling of being heavily burdened, mentally or physically, by trouble, adverse conditions, and anxiety. Here the theme of oppression is portrayed through the character of the Boss of Kafira who represents the group of elites described as oppressors and ill-treating the group of small people. This leads to the theme of revenge inflicted to the latter group. When the mass population as represented by students from Kafira University tried to complain against the bad governance of the ruling class through demonstration, the government sent soldiers to arrest them. Consequently, one of the demonstrators, Adika, was killed. We hear this from Doga, his father: "[...] People say there were many of them all marching in the same manner. Suddenly, the shooting broke out. People fled in all directions, but my son's lonely body lay in the middle of the street. Only four bullets were fired that day. Adika has four bullet wounds in his chest" (p.10). Besides, when Jusper was found to be guilty of murdering the subchief's brother, Boss of Kafira sent soldiers to kill his parents in revenge for his brother (p.25). In the story, people are meant to keep quiet and watch things happen in the way dictatorial leaders wish. However, many people have been arrested for political reasons. Here the target is those who dare to speak on behalf of change. For instance, Mosese was arrested for having spoken his mind when politicians tried to turn the funeral ceremonies into a political issue (p.29). Jere is another character arrested for letting Adika's parents go on with burial ceremonies while it was not allowed. So, this is also taken as an act of revenge since Mulili has been a promoter to Jere's imprisonment as a response to his attempt to shoot him during the dispute about burial ceremonies. Jere: Get out of my sight! (aims a pistol at him).Mulili: (hands up) Alright, I am sorrowful. I honest doesn't know it will affect you. Jere: Get out of my sight now! (Mulili begins to walk off. Jere shoots as Mulili dives off stage).Mulili: Hey you, what you thinks you do?! You shall pays for it! Jere: Go shoot your mouth wherever you will. ... Jere: My friend, why... Askari: Next time you call me your friend, you will lose a tooth. What makes me think I am a better man than you!? Do you think I live off answering such foolish questions? You are inside, I am out; now if that doesn't make sense to you, something else will (pp.20-21). Not only is arrest considered as a kind of revenge to those people who are against the political regime but also some of them have been killed. The instance is that of Kabito, one of the government officials murdered due to Mulili's betrayal (p.65). This is taken as revenge for the Boss decided his killing after hearing accusations from Mulili and seeing that Kabito, as one of his fellow leaders was really against him. On the other hand, victims also inflicted revenge. Normally, it is well known that a person or thing that suffers harm or death is victim. According to Webster's Revised Unbridged Dictionary (1998), victim is defined as one that is subjected to oppression, hardship, or mistreatment - $\mathrm{a}$ frequent victim of political attacks. Regarding this definition, one may say that many people suffer from political attacks specifically when there is socio-political misunderstanding. This has been the case in 
most of African countries during colonial and post-colonial era. Imbuga portrays the theme of victimhood in postindependent Kenya and shows how victims tried to take revenge to their victimizers. Jusper is the one whose brother was killed while Kafira University students were in demonstrations protesting against the government policy of hiring many expatriates while some of the citizens were able to perform the same tasks. As an act of his anger, he murdered the sub-chief's brother, (pp.16-17). Here, the author uses Jusper as an example of the mass who have been victims of their own ideas for change. They have suffered from oppression, hardship and mistreatment in many ways. However, to show that they are not happy of their way of living and of what was happening - torture, murder and arrest, they resort to the vengeance. In addition, Jusper continues his ideas of revenge where he said that he would never have rest with the death of his entire family on his mind. He continued insulting the ruling class saying that those brutes had murdered his parents in exchange for his release and had given him good treatment knowing well that he had had nothing else to lean on except his student status. And he went on saying that he would get his revenge someday, even if it meant going it alone, (p.37). Finally, the revenge Jusper is talking about in the above quotation is fulfilled towards the end of the story where he shot Mulili due to all bad things he had done to them in particular and to the society in general. This event happened when they were practicing the play for the final rehearsal. Remember that this play would be acted by prisoners. As one of the actors supposed to play the chief of staff was not well, so, the Boss decided to intervene and took the role of the chief of staff. As guns were some of the tools needed for the play performance and these prisoners were short of them, the Boss commanded his guards to hand over their guns. That moment, Jere and Mosese led by Jusper made a Coup d'Etat where Mulili, the cousin and close adviser of the Boss was condemned to death.Mosese: Jusper, stop where you are. Jusper: Give it to me! (Boss hands over the gun to Jusper. The latter stares at the weapon unbelievingly. Slowly he turns and surveys the people with his eyes. Finally, the eyes are fixed on Mulili. Now Jusper stands at attention.) Squad, attention! Aim! (He aims.) Mulili: (indicating Boss). Not me. It him! Jusper: Fire! (He shoots and Mulili's body slowly falls; now Jusper turns and surveys the people with his eyes once more). I did it for all of you people (p.77). the researcher also gives much attention the theme of corruption. According to Longman Group (1978, p.145), corruption which derives from the verb "to corrupt" means using one's power in order to get advantages for oneself. However, a person may be said to be corrupt when he/she uses his/her power in a dishonest, illegal or immoral way in order to get undeserved advantages. In fact, when corrupt people are found to be many in a society, the latter is qualified as a corrupt society. Moreover, most of government officials are channels of corruption. Kabito is corrupting university officers to get milk supply tender in vain because this tender was given to Mulili due to the Boss of Kafira, his cousin. This is revealed through the conversation betweenNicodemo and Kabito himself.Nicodemo: Did you get the potato? Kabito: What potato? Nicodemo: The university potato. Did your tender go through? Kabito: Don't remind me of things I would sooner forget. I sent the whole of last night being nice to people, only to lose the tender this morning (Imbuga: 1976, p.54).Furthermore, Privilege and favoritism have been characterized as indicators of corrupt society after independence.Ssenyonga (2012, p.360) defines favoritism as unfair generous treatment of one person. However, favoritism and privilege are two terms used interchangeably in that Macmillan English Dictionary defines the latter as a special benefit that is available only to a particular person or group. So, privilege is a type of corruption as well as favoritism. Below is the passage where the writer suggests the idea that the Boss is a corrupt man. He offers many privileges to Mulili, his cousin and due to these privileges he is forced to corrupt a University authority for the case of Mulili's tender using his power. Tumbo: Tender, did you say? Mulili: Yes, my tender for supply of milk to university. They gives it to unknown small man. So this morning, I says okay, we see if university authority know who man be head and neck of Kafira. So I wakes up, I go to my cousin to explanation him. Tumbo: You are sure you were with Boss? Mulili: One God! I tells him, he take a automatic direct telephone wire to university manager. Good, listen me. What happen to Mr. Mulili tender for supply milk? What? You knows who speaking? It is me, me Boss himself, no bloody vice-deputy. Yes, alright cancel now. Tender Mulili's (Imbuga, 1976, pp.56-57). The Boss of Kafira also uses his political power and government property to give Mulili, his cousin, many acres of land and cattle after his retirement from the army as a reward to his services of the nation. This is considered as favoritism because it is not done for everybody.Tumbo: The worst of the advisors is that cousin of his, Mulili. Regina: I understand he has been given a large farm for his services to the nation. Tumbo: It's true. That's why he retired from the army. He now calls himself a farmer (Imbuga: 1976, pp.47-48). Within the same line of ideas, most of government officials in Kafira are not interested in the national development or the development of the people but they are rather busy with the size of their income generation. Embezzlement and robbery of the government 
resources and budget are their main concern. This is justified by the discussion they had altogether about the size of potato during the sessions preparing the Head of State visit. Nicodemo: Yes, what size of potato per hour? Tumbo: You will be paid per day, not per hour. Nicodemo: How many working days do you think...? Kabito: Of course it will be necessary for us to meet every day until the visitor arrives. In fact, I think it will be necessary for us to meet after the visit for the purpose of review. Nicodemo: And remember also Mr. Chairman that the potato you get will be directly proportional to the potato we get (Imbuga: 1976, p.56). Finally, Tumbo is described as a good example of a corrupt man. Apart from being nepotic, he also misuses the government money for play competition for his own profits. This kind of embezzlement is not good for a trustworthy leader. Tumbo: Good. Now of the six hundred pounds that was to finance the competition, I give one third to the two of you. The other two thirds will be used to put the records straight. But remember all this is in strict confidence. Your prize money will be sent to you as soon as the results of the completion are made public. Regina: I still feel that... Tumbo: Jusper, tell your cousin that we are here for only a season (Imbuga: 1976, p.52). For nepotism,Ssenyonga (2012, p.362), defines it as favoritism shown to relatives or friends especially by giving them jobs. Nowadays, nepotism is common accusations not only among government officials but also private sector. This happens when a relative of powerful figure gets a job without qualification. In Betrayal in the City, the Boss of Kafira shows nepotism by giving job to Mulili, his cousin. He also puts him in an entertainment committee in order to report all inconveniences to him on time. Boss: Come on, get on with it. Mulili: Boss, you are cousin and I tells you this. Things have spoil. Don't trust anybody, not even me. Boss: You talk straight or go back to the meeting. I put you on the committee for obvious reasons and I expect you to report directly to me if something should seem to be going wrong. What is the matter? (Imbuga: 1976, p.61). In fact, all acts of evils displayed by Mulili in the play it is because he is an eye and ear to the Boss of Kafira. And remember he is his cousin. Mulili is also overconfident to tell everyone about the future promises from his cousin now in power. He expresses this in these words: My future depend on this. If I keep law and order, a big farmer I become when I retired. Boss promise me that and you know...I be his eye and his ear here. I say no ceremony Imbuga (1976, p.18). Moreover, Tumbo is once again a character in the play displaying all forms of corruption such as privilege, favoritism and nepotism as a kind of corruption. When it was time to select a play intended to be performed on the visiting day of the head of Kafira, Tumbo declared
Regina's cousin, Jusper, the winner without competition. That is nepotism. Why? The idea behind is that Tumbo likes Regina and her cousin, Jusper is given this privilege due to the friendship. Consequently, what is noticed here is that this kind of privilege promotes betrayal in such a way Tumbo betrayed many people who may have participated in the play-writing competition and probably won it (Imbuga: pp.47,51). Afterwards, illiteracy in this work of art is more frequent here and there. That is the case of Mulili who is assigned different responsibilities in the government being unqualified because of nepotism and favoritism. Being illiterate is justified by his command of English all along the play. Let us for instance analyze one of his words. Who do they thinks they are not to cooperate? We pays for their fees, we pays for their luxury food, we give them all necessary, who are they? We should can force them to acting (Imbuga: 1976, p.59). Nevertheless he should simply say: Who do they think they are not to co-operate? We pay for their fees, we pay for their luxury food, we give them all necessary. Who are they? We should force them to act. In addition, illiteracy and incompetency go hand in hand. Mulili is incompetent. Instead of performing well his duties he is preoccupied by gossip, betrayal and revenge. During entertainment committee, some government officials who are now in the committee suspect his ineptitude. Nicodemo: I understand that Tumbo was forced to have him on the committee for security reasons. Kabito: As far as I am concerned, Mulili is an army drop-out and a second-rate farmer. What does he know about entertaining an important visitor? This is not an agricultural show. If he doesn't get me first, I will get him. Nicodemo: Report the matter to Boss first. Kabito: Are you new here? You should know that to report Mulili is to dig your own grave (Imbuga: 1976, p.54-55). In addition, Tumbo is incompetent, too. He is unable to proofread the play and make sure what it is all about. He puts all the trust in Jusper, a student who was once expelled from university because of his radical ideas. The latter was not happy with the government for hiring a big number of expatriates ignoring their own people. Tumbo: You know, I have not had the chance to go through the script. Jusper: But then you have been busy. Tumbo: That is no excuse. If he should ask for the story of the play, I will point at you and say, "Your Excellency, the author of the play is better qualified to give that information." I trust you will face him and answer that question with precision (Imbuga: 1976, p.67-68). And eventually, tumbo is probably illiterate and does not have enough intellectual capacity to run different responsibilities in the government. He said it somewhere in the play that he has sold his scholarship because his family was poor to mean he does not have university skills as a high government official. He 
does not value the importance of education. Jusper: I suppose it's as much as you drank off the pocket money you got during your university days. Tumbo: (a bit embarrassed) Actually, I ... well, I was never there really, but ... I mean ... I qualified alright but my family was so poor that I decided to sell the scholarship. ... Tumbo: I had to work, but I don't regret it. Education no longer matters these days (Imbuga: 1976, pp. 44-45). Regarding loss of trust, people do not trust their leaders. Longman Dictionary of Contemporary English (1995) defines trust as a strong belief in the honesty, goodness etc. of someone or something. Contrary to this definition, when you are betrayed by someone, it is likely that you will not easily trust them anymore. Trust is fragile and can be lost instantly. Even a long-earned trust may be eroded and then suddenly lost. For instance, Christ has trusted Judas, one of the twelve apostles. But Judas betrayed Christ by selling him to his enemy. However, the trust Christ and Judas's fellow apostles had in him was lost, (Luke 22:3-6; 47-48). People in Kafira are also hopeless and disillusioned. They are disappointed by their fellow elites who do not fulfill the promise of freedom and independence. Mosese is an example of this hopelessness. He does not trust the government. He said: "It was better while we waited. Now we have nothing to look forward to. We have killed our past and are busy killing our future." (Imbuga: 1976, p.32). In addition, Doga, Jusper's and Adika's father does not trust the government. He lost hope. He says: "Hope? I am surprised that you still talk hope. Nina, we buried hope the day Adika was gunned down. Come, let us not waste any more time. Get me soil (Imbuga: 1976, p.8). Doga's loss of trust towards the government is revealed when his son Adika was killed in the students' demonstration. He was talking to his wife, Nina about the incident and rituals performance. She wanted to report the matter to the subchief but Doga refuses because he does not trust him. Nina: It would be wrong for us to sit on this evil. We cannot outwit our ancestors. Let us do what is expected of us. Let us send word to the sub-chief and... Doga: The sub-chief! Who is the sub-chief? A mouse does not share a bowl with a cat. Nina: It is the noise he makes that I fear. Doga: The sub-chief! Who is the sub-chief? Have you ever so soon forgotten the rumour that now bears the same weight as a noble truth? Nina, when dry thunder tears the sky before our eyes, do we forget the storm of yesterday? Women!! Women will never think beyond the beds upon which they hide for the night, the sub-chief! Did he not come from that same stomach that mothered Chagaga? Imbuga (1976, p. 9). Still Regina is disillusioned and she loses hope of future life. She is afraid of what is coming next since people who try to raise their voices for the voiceless are killed and others jailed for nothing. She is now pessimistic. Jusper: It doesn't matter what the masses think if they have no voice. That is why Adika had to go. That is why Mosese and Jere are in because they tried to provide voices for the masses. They are all strong men. Regina: What is strength in a world such as ours? What did they stand to gain by shouting louder than the rest? Nothing. They simply put a lock to their past. (Imbuga: 1976, p.39). Similarly, dictatorship is another kind of evil suffered by Africans in general and Kenyans in particular. Dictatorship is normally a type of government where absolute sovereignty is allotted to an individual or a small clique. The Boss of Kafira has the total power but he misuses this power to rule the people. He is a dictator in all possible manners. Instead of protecting the people he is the one who destroys them. Let us take an example of these students of Kafira University who are protesting against the way the government is hiring expatriates. The government uses violent forces to stop the students' riots where Adika is shot. In fact, the Boss does not even need to take any resolution about the students' complaints. He rather increases the number of expatriates as a sign of his dictatorship and terrorism. Boss: In a way, it was very sad. They should have known my arms are long. My eyes see far, and my ears are the sharpest on the continent. Am I wrong?Tumbo: (still nervous) Yes, sir. Boss: Wrong? Tumbo: Who, you sir? No! Never! Boss: No one who shouts at me ever get what they want. You saw what happened the last time, didn't you? Jusper: Yes, Your Excellency. Boss: Because they shouted against the appointments, five of which were my own personal appointments, I deliberately sent in an order for three hundred more expatriate personnel, just to put them in their place (Imbuga: 1976, pp.70-71). Within the same line of ideas, the government sends soldiers to stop the shaving ceremony for Adika. Doga and Nina, his parents quarrel with them which causes their death later. These soldiers are now violating human rights. Finally, the Boss is a true dictator and his regime is characterized by violence and killings of innocent people. His dictatorship is everywhere in the play. The Boss also uses dictatorship to intimidate the university to give tender to Mulili (Imbuga: 1976, p.57). Mulili betrays Kabito to the Boss. He accuses him false accusations. When the Boss hears all this he commands Mulili to put an end on his life. Mulili: I can't know. But I suspect Kabito. Boss: When a man plays with fire, he gets burned. He will serve as an example to others that may have hot mouths like him. Mulili: I look at him and said to myself: "This man is fit to go mental." Boss: Go get him. Take two guards with you and bring him to me. No, wait a minute. I shall not set my eyes upon him. Mulili! (Imbuga: 1976, p. 63). Similarly, the above ills go hand in hand with social injustice. Although it is a 
complex idea that is difficult to define, in general social justice could be seen as the fair distribution of resources, advantages, assets and benefits among all members of society (Ryan: 2015, p.115). Where there is lack of social justice it is said to be social injustice. However, it would be difficult not to notice where social justice is missing in today's world. Ryan (2015) defines social injustice as where people in our society do not receive equal access to resources and opportunities, such as a home or education. After the independence, Kenyan society has suffered social injustice. The readers who read this research study will see that some people's needs are not met, while others have more than enough. For instance, true Kenyans do not have equal access to job opportunities and other rights like Adika's parents who are denied to perform shaving ceremony for their son (Imbuga; 1976, p.18). People are unable to participate fully in society so they become voiceless and their problems do not go away. In addition, those who have do not speak up for those who have not. A good example is that of Tumbo and other government officials who know quite well that people are not happy at all. But instead of doing advocacy for the voiceless they only defend their own interests. They do not want any socio-political change in Kafira. They do not want to lose bread. Tumbo: there are opportunities, but they don't come on a plate. Jusper: The opportunities you talk of can only be described as potential and you know how everlasting these potentialities can be. Tumbo: You students talk too much. This country needs men of action. If I have depended on empty talk when I came back from abroad two years ago, I would not be owning this block and that other one. You were born alone, and when you die, you will die alone. Why then do you want to ruin your chances by pretending to talk for others? We are here for a season. That is what you students don't understand. You won't be a student forever, you know. Learn to fight for yourself and then when your presence is felt, you can risk shouting for others (Imbuga: 1976, p. 45). Simply put, people who claim for social justice are treated badly in the society. We see Mosese who tried to speak his mind is now in jail. Jere is also in prison because of standing for the truth and justice. Kabito is another character in the play who got fatal accident after quarreling with Mulili, a betrayer. Finally, these students of Kafira University were claiming for social rights and justice in their country during the manifestation. But as a result, one student was gunned. So, each and one in this society is claiming for socio-political change.Other way round, no one can ever live without wronging. No one is perfect in this world full of many evils. That is why some strategies-forgiveness, unity and reconciliation are to be taken in order to have peace of heart. According to Macmillan English Dictionary (2002), reconciliation means a new and friendly relationship with someone you argued with or fought with. Whereas unity is a situation in which a group of people or countries work together for a particular purpose. Referring to this definition, one can say that apart from forgiveness, unity and reconciliation can serve as strong solutions to overcome conflict, betrayal, revenge and any other kinds of social injustice. Therefore, they can be considered as the basis for durable peace, security, human rights, and development. Tutu (as cited in Wilson, 2001, p.120) introduces forgiveness and reconciliation as a way to a peaceful and healing process: Forgiveness is not conditional upon the wrongdoer expressing remorse or asking for forgiveness, but is a duty incumbent upon all victims. There are no unforgivable perpetrators, no person who cannot be redeemed and this redemption also "liberates the victim."[...] any expression of a desire for revenge by victims would seem out of place. Virtues of forgiveness and reconciliation were so loudly and loudly applauded, that emotions of vengeance, hatred and bitterness were rendered unacceptable, an ugly intrusion of a peaceful, healing process. According to His Excellency Mgr. Desmond Tutu, forgiveness is a strong weapon for heartbroken healing. In Betrayal in the City, in the beginning Mosese does not want to forgive the government who have jailed him for no reason and sent soldiers to beat her innocent sister. But in the end he changes his mind. He discovers the goodness of forgiveness and promise to forgive. Mosese: Buying my release by acting in front of a visiting head of state would be to betray our cause. Why do people sit and watch in silence as the disease spreads deep inside? I will never forgive them. They watched in silence as soldiers beat up my innocent sister, forcing her to give evidence against me. Jere: Mosese, are you sick? Mosese: Yes, that is why I am accepting the post. No, I will forgive but I will always remember that I forgave them (Imbuga: 1976, pp.32, 34). With regard to truth and reconciliation, intentionally, these two are steadily becoming more important issues. Reconciliation is as relevant for the international community as for the nation itself. One of the most shocking features of international politics is that some governments have never been held responsible for massscale killings, even though the same government remained in power long afterwards. However, central to the process of reconciliation, and indeed to all work for human rights, stands the need to establish the truth. Without truth no justice can be done, no mediation can bring results, and compensation measures lack real meaning. It is also said that no true reconciliation is possible unless there has at the very least been the chance to bring the worst offenders to justice Bronkhorst (1995, pp.145, 152). Truth, then, the 
recognition and acknowledgement help to provide the basis for a workable political community; it will help to provide it with legitimacy and durability. Truth is only useful to reconciliation in some ways and: "unless it is joined to a form of justice other than punishment, the recognition of truth is likely to breed outrage in victims and fear in beneficiaries" Christie (2000, p.180). Any genuine reconciliation is not possible without the telling of the truth and without the public acknowledgement of that truth: There can hardly be reconciliation without an acknowledgement of the wrongs being done to the victims of human rights violations, without the nation as a whole participating in the healing process... it is fallacy to believe that reconciliation can be built on the basis of collective amnesia Christie (2000, p.164). Bringing Bronkhorst and Christie's observations into life, we see at the end of the play, forgiveness and reconciliation between two parties in opposition: the oppressed and oppressors. A coup d'état led by Jusper, Jere and Mosese puts an end on dictatorship, oppression, and all types of people's misery. Boss is reconciled with his opponents. Boss: You mean you will not kill me? Jere: No. what do we stand to gain by your death? Nothing. Our wish was not to swim in human blood, but to provide a mirror for Kafira. A mirror that will reflect the real faces of Kafira's front men. But it is not enough to provide only a mirror. No. we must learn to sacrifice ourselves for a better future. A future where these events that now take place need not be repeated (Imbuga: 1976, p.76). Tumbo also repents all mistakes he has done in this corrupt government and asks for forgiveness. So he is forgiven as a sign of reconciliation. Mosese: A future where men like him (Mulili) need not be members of our society. (toTumbo) But we thank you; it was largely through your inefficiency that we have achieved this. So go, depart from our midst. (Tumbo hesitates then speaks). Tumbo: I am truly sorry, but I am not entirely to blame. I was trained, but given the wrong job. Once again I am sorry (Imbuga: 1976, p.76). After analyzing the ills of post-independent Kenyan society and solutions to overcome them, here comes the relevance of the research to the society. This research study is important for the African society in general and Kenyan community in particular. It comes on good time when people need to know deeply the ills of post-independence in Africa, Why Africans suffered a lot instead of enjoying the happy life as expected and what is needed in order to build a strong and prosperous nation free from betrayal, revenge, social injustice, conflicts, corruption, nepotism, favoritism and dictatorship to name a few. People who will have chance to read this work of art will undoubtedly change their way of thinking and living because this study will equip them with scientific and constructive ideas which will enable them to react positively against the wrongdoing actions that may arise in their communities. Political leaders who may have the same principles of ruling like Boss of Kafira will surely change their political mindset and strive for the better life of their fellow citizens. Remember most of African countries are facing the issue of civil wars and socio-political conflicts. This study will teach those who are concerned how to overcome such conflicts through truth, forgiveness and reconciliation as strong weapons for sustainable development and stable peace building.

\section{SUMMARY OF THE FINDINGS AND CONCLUSION}

The findings revealed that Betrayal in the City is a good play which reflects mostly the lives of people in the world. The themes found in the play are the elements that we often come across in fictional literary works. The researcher has tried to highlight socio-political problems of Africans from colonial to post independent African society in general and Kenyan community in particular. This study portrays all kinds of evils of Kenyan leaders and the suffering of the mass as extracted in Imbuga's play, Betrayal in the City. Also a scientific study and critical analysis of themes related to evils such betrayal and revenge, corruption, nepotism and favoritism, and dictatorship among others have been a great deal of our literary study. In brief, we have noted how the above ills have handicapped Kenyan society after independence. We have also investigated how truth and reconciliation are steadily becoming more important issues. Reconciliation is as relevant for the international community as for the nation itself. However, forgiveness and reconciliation have been appreciated as a key towards unity and sustainable peace building among people. Lastly, the relevance of the study to the society has been put in the readers' hands.

\section{REFERENCES}

[1] Achebe, C. (1966). A Man of the People. London: Heinemann.

[2] Achebe, C. (1958). Things Fall Apart. London: Heinemann.

[3] Bayart, F. J. (1993). The State in Africa: The Politics of the Belly. London: Longman.

[4] Bazimaziki, G. (2016). The Depiction of Human Society Through Epic Literary Genres: A Comparative Perspective of the Function of Two Afrcan Heroic Epics. International Journal of English and Literature. Vol.8, pp. 63-73.

[5] Boveri, M. (1971).De la Trahison au XX ̀̀me siècle. Paris: Gallimard.

[6] Bronkhorst, D. (1995). Truth and Reconciliation: Obstacles and Opportunities for Human Rights. Amsterdam/ Amnesty International Dutch Section. 
[7] Christie, K. (2000). The South African Truth Commission. London: Macmillan Press.

[8] Gecau, K. (1973). The Various Levels of Betrayal I Wreath for Udomo in Chris L. Wanjala (ed). Standpoints on African Literature. Nairobi: E.A.L.B.

[9] Hamadi, L. (2014). Eduard Said: Post Colonialism Theory and the Literature of Decolonization. PhD. Lebanese International University.Retrieved June 26, 2016 from European Scientific Journal Vol.2.

[10] http: www.psychcentral.com/lib/2007

[11] http://www.wikipedia.org

[12] International Bible Society (1984).The Holy Bible. Mexico: International Bible Society.

[13] Imbuga, F. (1976).Betrayal in the City.East African Publishers.

[14] Macmillan Publishers (2002).Macmillan English Dictionary for Advanced Learners. London: Macmillan Publishers Limited.

[15] McGinnis, A. (1973). The Friendship Factors. New York: Augsburg Publishing House.

[16] Mukama, I. (1999). The Theme of Betrayal in Postindependent African Literature: The Case of Ngugi. Unpublished. B. A. Dissertation. Butare: National University of Rwanda.

[17] Muzerwa, J. P. (2006). The Theme of Human Sufferings in Kofi Awoonor's This Earth my Brother. Unpublished B.A. Dissertation. Butare: National University of Rwanda.

[18] Ngugi, T. (1964).Weep not, Child. London: Heinemann.

[19] Ngugi, T. (1967).A Grain of Wheat. London: Heinemann.

[20] Nkrumah, K. (1965). Neo-colonialism: the Last Stage of Imperialism. Retrieved on August 02, 2016 from https: www.marxists.com

[21] Ogungbsan, K. (1978). New West African Literature. London: Heinemann.

[22] Ryan, P. (2015). Handbook of Civic Education. Nairobi: Franciscan Kolbe Press.

[23] Ssenyonga, M., A. (2012).Reflections in General Paper: A Comprehensive Guide. Kampala: King's College Budo.

[24] Summers, D. (1995).Longman Dictionary of Contemporary English. London: Macmillan Publishers.

[25] Sykes, J. B. (1982). The Concise of Oxford Dictionary of Current English Based on the Oxford English Dictionary and its Supplements.London: Oxford UniversityPress.

[26] Verdier, R. (1980). La Vengeance: Etudes d'Ethnologie, d' Histoire et de Philosophie.Paris: Editions Cujas.

[27] Webster, M. (1979).Webster's Revised Unbridged Dictionary. Massachusetts: MICRA.

[28] Wilson, R. A. (2001). The Politics of Truth and Reconciliation in South Africa: Legitimizing the Postapartheid State. Cambridge: Cambridge University Press. 